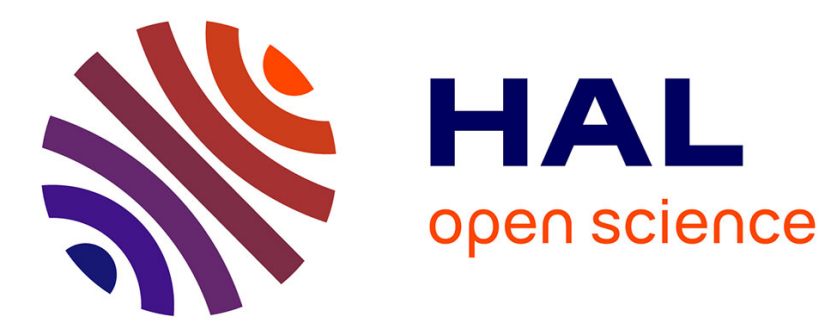

\title{
Andaman Ophiolite: An Overview
}

Debaditya Bandyopadhyay, Douwe J van Hinsbergen, Alexis Plunder, Pinaki

C Bandopadhyay, Eldert L Advokaat, Soumi Chattopadhaya, Tomoaki Morishita, Biswajit Ghosh

\section{To cite this version:}

Debaditya Bandyopadhyay, Douwe J van Hinsbergen, Alexis Plunder, Pinaki C Bandopadhyay, Eldert L Advokaat, et al.. Andaman Ophiolite: An Overview. The Andaman Islands and Adjoining Offshore: Geology, Tectonics and Palaeoclimate, 2020, 10.1007/978-3-030-39843-9_1 . hal-02495710

\section{HAL Id: hal-02495710 https://hal.science/hal-02495710}

Submitted on 30 Mar 2020

HAL is a multi-disciplinary open access archive for the deposit and dissemination of scientific research documents, whether they are published or not. The documents may come from teaching and research institutions in France or abroad, or from public or private research centers.
L'archive ouverte pluridisciplinaire HAL, est destinée au dépôt et à la diffusion de documents scientifiques de niveau recherche, publiés ou non, émanant des établissements d'enseignement et de recherche français ou étrangers, des laboratoires publics ou privés. 


\title{
Andaman Ophiolite: An Overview
}

\author{
Debaditya Bandyopadhyay, Douwe J. J. van Hinsbergen, Alexis Plunder, \\ Pinaki C. Bandopadhyay, Eldert Advokaat, Soumi Chattopadhaya, \\ Tomoaki Morishita and Biswajit Ghosh
}

\begin{abstract}
The Andaman Ophiolite remained little explored for long but recent studies yielded important first-order findings that hold promise for further research. Here we summarise these first-order constraints on the structure, geochemistry, and evolution of the Andaman Ophiolite and identify key frontiers for future research. The uniqueness of Andaman Ophiolite is their petrological and geochemical diversity in a
\end{abstract}

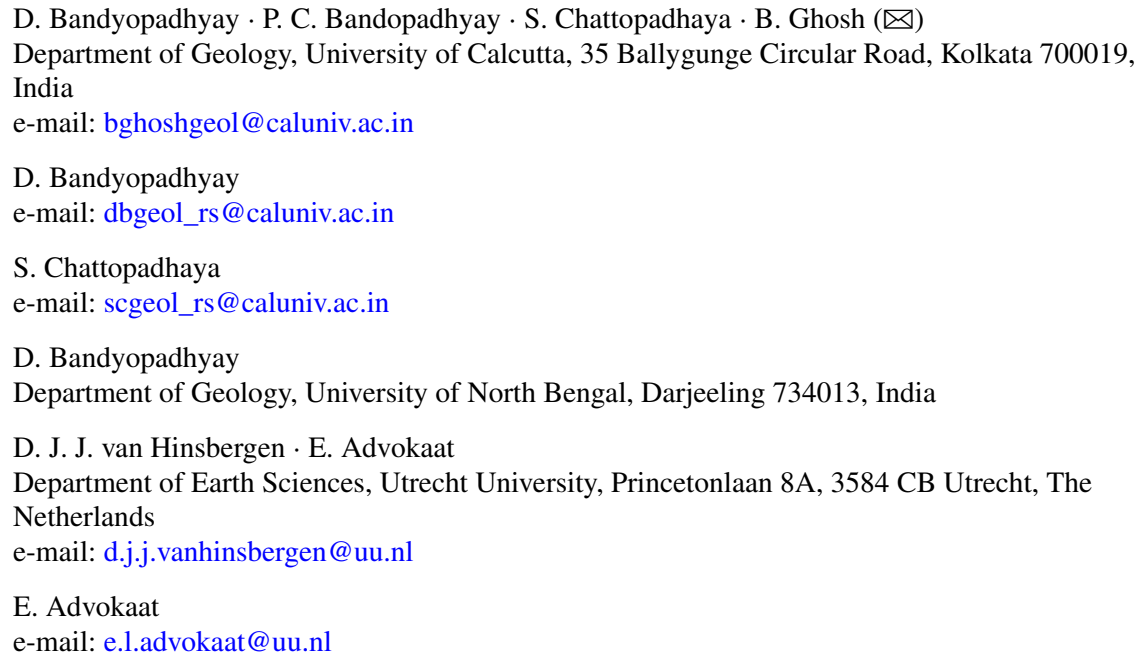

A. Plunder

BRGM, 3 avenue Claude Guillemin, BP 36009, 45060 Orléans Cedex 2, France

e-mail: a.plunder@brgm.fr

\section{E. Advokaat}

Department of Physical Geography, Utrecht University, Princetonlaan 8A, 3584 CD Utrecht, The Netherlands

\section{T. Morishita}

Faculty of Geosciences and Civil Engineering, Institute of Science and Engineering, Kanazawa University, Kanazawa 920-1192, Japan

e-mail: moripta@se.kanazawa-u.ac.jp 
close spatial association. Among many unresolved issues the age, stratigraphic coherence, and emplacement mechanisms of Andaman Ophiolite remain enigmatic. In particular, although many of the elements of the typical ophiolitic pseudostratigraphy are present, they are not found in structural coherence, and available geochronological constraints suggest a much longer than normal time window for the amalgamation of the ophiolite's crust. We raise questions on the plate tectonic setting and evolution of the ophiolite, suggesting that a multi-phase history of magmatism and ophiolite evolution is one of the key questions that deserves international geoscientific attention.

Keywords Andaman Ophiolite $\cdot$ Subduction initiation $\cdot$ SSZ setting $\cdot$ Arc maturity

\section{Introduction}

Ophiolite investigations have always played a pivotal role in testing and establishing hypotheses and theories in plate tectonics, both on the evolution and dynamics of spreading ridges as well as on the juvenile stages of subduction. The suboceanic origin of ophiolites in various tectonic settings and their emplacement onto continental margins or accretionary prisms have been the topics of a dynamic and continually evolving concept since long (Coleman 1971; Anonymous 1972; Dewey 1976; Shervais 2001; Dilek and Furnes 2011). Earlier debates were centred on establishing the relationship between ophiolites and modern oceanic lithosphere analogues, specific to tectonic settings. The apparent conflict between geochemical-petrologic evidence for derivation of magmas from highly depleted mantle similar to that found at modern subduction zones, and structural-stratigraphic evidence for seafloor spreading in a non-island-arc environment led to the so-called ophiolite conundrum (Dilek and Moores 1990; Moores et al. 2000).

However, global investigations in last two decades have demonstrated that fossil oceanic lithosphere preserved as ophiolites in most orogenic belts, is petrologically and geochemically diverse. Oceanic crust may form in any tectonic setting, at midocean ridges, and in the upper plate close to, or distal from subduction zones and based on their geochemical composition they are classified into subduction-related and subduction-unrelated ophiolites (Dilek and Furnes 2011). Suprasubduction zone (SSZ) ophiolites, those formed close to subduction zones have the highest likelihood of becoming thrusted upon continental margins or accretionary prisms and are thus by far the dominant ophiolite-type, constituting $~ 75 \%$ of the Phanerozoic ophiolites. Geochemical fingerprinting clearly substantiates the role of subduction zone derived components in development of SSZ ophiolitic magmas (Beccaluva et al. 1994; Bedard et al. 1998; Dilek et al. 1999; Shervais 2001; Dilek and Flower 2003; Dilek and Furnes 2009, 2014). On the other hand, mid-ocean ridge (MOR) ophiolites are relatively lower in abundance, but not rare, making up $\sim 20 \%$ of the population 
(Furnes et al. 2014). Exclusive MOR ophiolitic crust may be found where intraoceanic subduction was not associated with upper plate extension to form SSZ ophiolites. It may also be found together with SSZ ophiolitic crust where it represents the pre-existing lithosphere within which SSZ spreading occurred (e.g., Maffione et al. 2015). Nevertheless, forearc, embryonic arc, and backarc settings in suprasubduction zones are the most widely documented tectonic environments for the origin of ophiolites. Magmatism during each stage of subduction, from infancy to maturity produces spatially and temporally associated, mafic-ultramafic to highly evolved rock assemblages. These rock units, which have varying internal structures, geochemical affinities, and age ranges, and originally formed in different geodynamic settings, constitute discrete ophiolite complexes and can become tectonically juxtaposed in collision zones (Dilek 2003).

In the present geodynamic configuration of SE Asia, the modern northern collisional plate boundary of the Indian plate along the Main Frontal Thrust of the Himalaya extends south from the eastern Himalayan syntaxis through Nagaland, Manipur and the western Burma (Myanmar) region and merges with an oceanic subduction system along the Andaman-Sumatra-Java (ASZ) trench where the Indian plate is downgoing below the intensely deformed SE Asian tectonic collage in the upper plate (e.g., Hall 2002). The Andaman and Nicobar Islands form the outer arc high, and are composed of remnant ophiolites and underlying mélange, a Palaeogene-Neogene clastic sedimentary cover, overlying a Neogene accretionary prism (Bandopadhyay and Carter 2017a). To the west, this outer arc is bordered by the ASZ trench and to the east there occur two volcanic islands (Barren and Narcondam) that belong to a volcanic arc extending from central Myanmar Basin in northern Myanmar and continues eastwards into Java (Acharyya 2007) (Fig. 1).

Discontinuous occurrences of ophiolitic rocks in the Andaman and Nicobar Islands have been known for over fifty years (Karunakaran et al. 1964, 1967) and were described as dismembered bodies in reviews of "Ophiolites in SE Asia" (Hutchison 1975). Although the geographic positions of these ophiolites are strategic from the petrological point of view as they provide an important transitional link between the Himalayan collision zone and the Indonesian arc system, they have remained unexplored and elusive for long because of the natural isolation and inaccessibility to these islands. However, the active seismicity all along this convergent boundary as manifested by the 2004 Sumatra earthquake, and hazards posed by volcanisms at Barren Island have received attention of many workers, particularly in the last decade (Pal and Bhattacharya 2011; Sheth 2014; Sheth et al. 2009). Recent and active studies have focused on the ophiolites to establish their geodynamic setting of formation and evolution, and to fit them in Tethyan plate tectonic context. The first order findings have been documented well, yet the critical questions are still unresolved. This chapter examines the current state of knowledge on Andaman Ophiolite and discusses the scope of future research. 


\section{What Are the First Order Findings?}

Ophiolites crop out along the east coast of North, Middle, South Andaman and Rutland Islands. An idealized coherent ophiolite stratigraphy is nowhere exposed in the islands, different elements of the Penrose sequence (Anonymous 1972) are arguably present as dismembered units, scattered in isolated occurrences throughout the islands. The exposed lithological units in South Andaman (and Rutland), Middle, and North Andaman comprise a tectonized, restitic mantle sequences (>700 m thick in north- Andaman) hosting chromitite pods, an intrusive crustal cumulate sequence (up to $150 \mathrm{~m}$ ) and volcanic rocks (up to $400 \mathrm{~m}$ thick in south-Andaman) (Fig. 2).

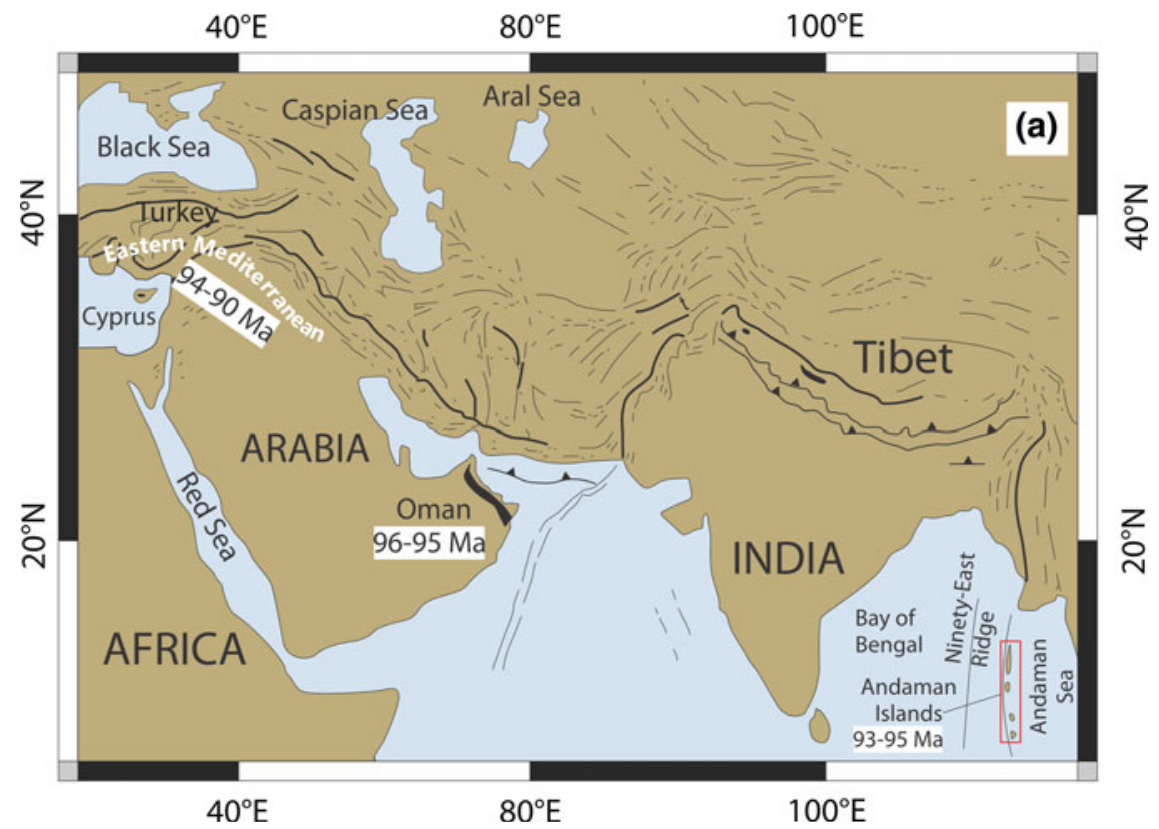

Fig. 1 a Distribution of eastern Neotethyan ophiolitic suture zones (thick black lines) (modified after Pedersen et al. 2010). Ophiolite locations of Eastern Mediterranean, Oman and Andaman along with $\mathrm{U}-\mathrm{Pb}$ zircon dates [in white box] are marked; b Colour-shaded relief image showing eastern Himalayan syntaxis, the western Burma (Myanmar) region and the Andaman-Sumatra-Java (ASZ) trench in the regional geodynamic framework. Major tectonic features are redrawn from literatures (Awasthi 2017; Liu et al. 2016; Imsong, et al. 2016; Sheth 2014). Relief data are from ETOPO1 Global Relief Model (http://www.ngdc.noaa.gov/mgg/global/). Pink triangles represent Holocene volcanoes (after Sheth 2014). LA: Little Andaman; CN: Car Nicobar; NI: Nicobar islands; GN: Great Nicobar; EMF: Eastern Margin Fault; DF: Diligent Fault; WAF: West Andaman Fault; BI: Barren island; NI: Narcondam island; AR: Alcock Rise; SR: Sewell Rise; STDS: South Tibetan Detachment System, MCT: Main Central Thrust, MBT: Main Boundary Thrust, MFT: Main Frontal Thrust. Geochronological results available in the regions (yellow stars with red outline), are also shown for reference (see text for details) c Geologically mapped ophiolitic regions (marked with thick black lines) of Andaman Islands over processed-hillshade map (generated using SRTM digital elevation data with a resolution of 1 arc-second from USGS Earth Explorer https://earthexplorer. usgs.gov/). North-South extending Jarwa Thrust is also shown 

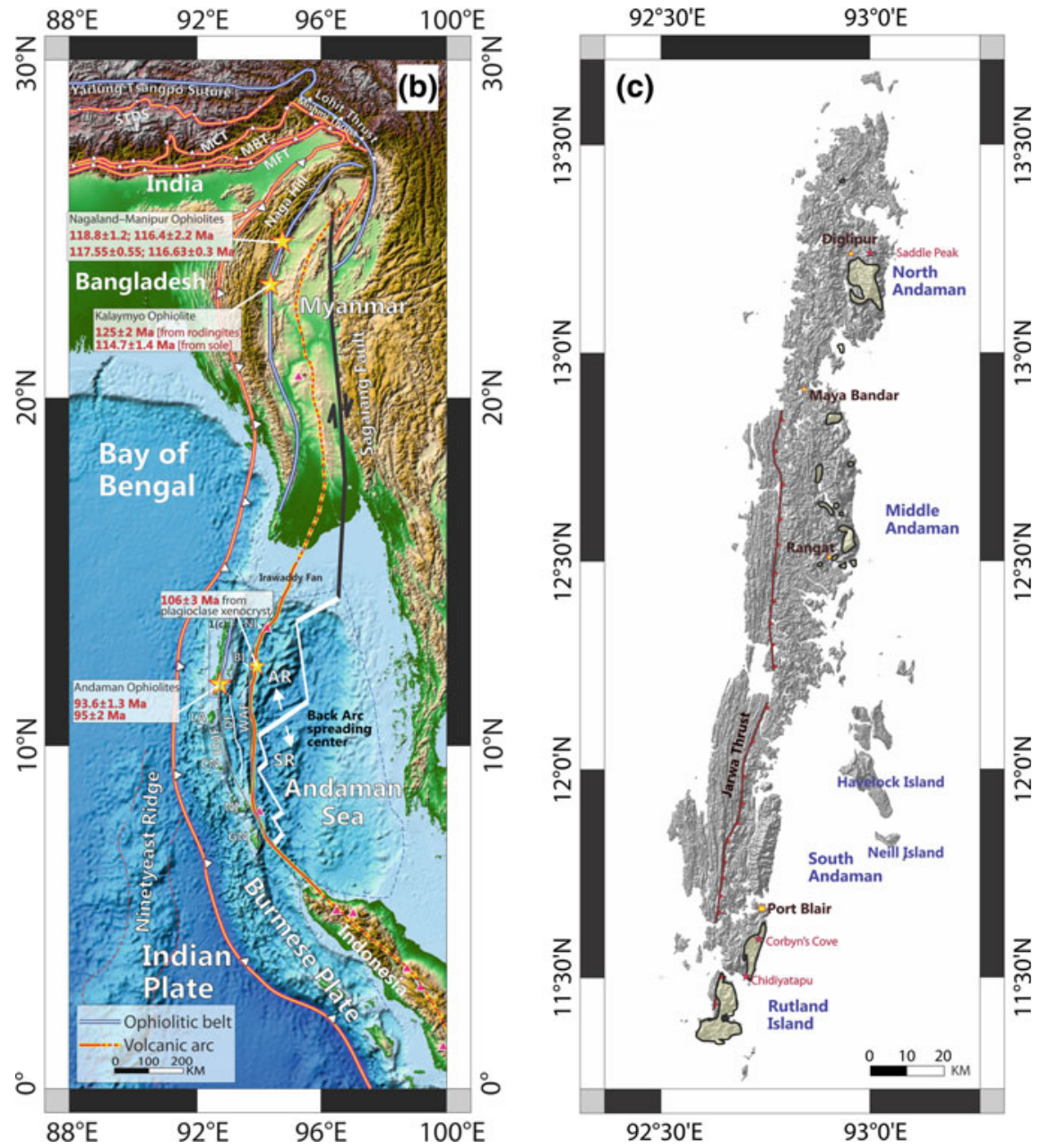

Fig. 1 (continued)

The Andaman Ophiolite and overlying Palaeogene stratigraphy have been thrusted and shortened, and are collectively thrust westwards upon an accretionary prism of deep-marine post-Eocene turbidites along the Jarawa (or Jarwa) Thrust that is traced over all islands (Bandopadhyay and Carter 2017a) (Fig. 1c).

Detailed field, petrographic and petrologic description of the various lithological units are beyond the scope of this chapter but may be found in the cited literature. Here we present a summary of the work done based on geochemical fingerprinting of the Andaman ophiolitic rock units. Since most of these works are pivoted around either the mantle rocks or the volcanics, we excluded other rock types in this section. 


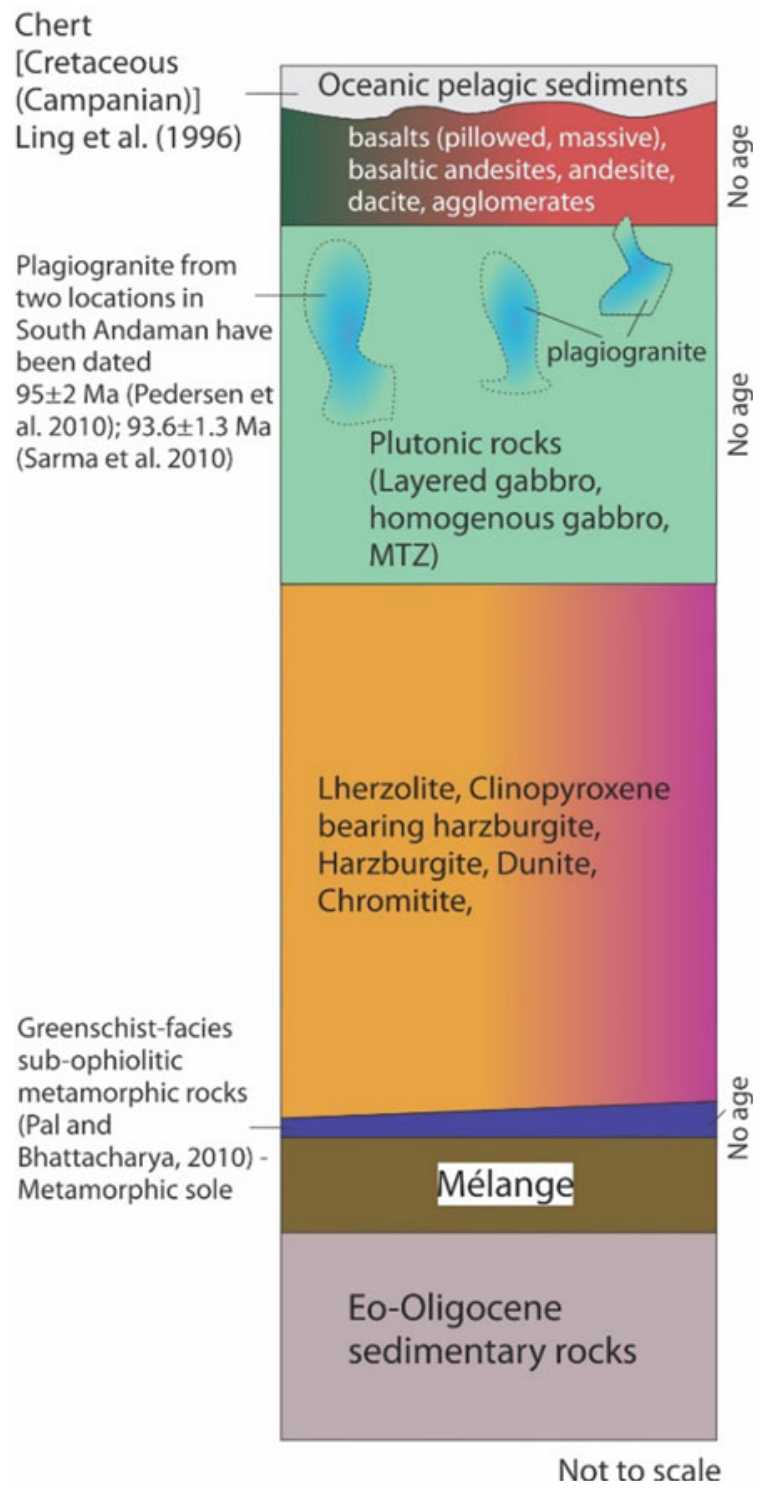

Fig. 2 Schematic (pseudo)stratigraphy of Andaman Ophiolite (not to scale). Various lithomembers belonging to volcanic rocks and mantle peridotites are shown in their respective positions, however their true genetic and stratigraphic interrelationship are ambiguous. Geochronogical information of the corresponding rock types, where available, have been summarized, thus showing potential gap areas in the age constraints 


\subsection{Contrasting Mantle Rocks}

In terms of petrography and mineral chemistry of the ophiolitic rocks, especially the mantle sequence, a pronounced variation exists between Rutland Island in the south and Middle and North Andaman towards the north (Ghosh et al. 2013). The composition of chromian spinels and clinopyroxenes from the harzburgite-dominated mantle rocks of the Andaman ophiolite on Rutland Island was inferred to be residue of 14$18 \%$ melting of a fertile mantle (e.g., DMM; Workmann and Hart 2005) in a suprasubduction zone environment (Ghosh et al. 2009, 2018). On the other hand, the mantle peridotites in Middle and North Andaman Island are distinctive, corresponding to $<10 \%$ mantle melting with minor flux infiltration (Morishita et al. 2018), and mostly belong to relatively fertile lherzolite that occasionally grades to clinopyroxenebearing harzburgite with a geochemistry that instead suggests formation in a backarc setting (Ghosh et al. 2018) (Fig. 3).

Finally, the peridotites on Middle and North Andaman are underlain by a serpentinite-hosted melange that contains metavolcanic rocks and metacherts with greenschist facies to amphibolite-facies metamorphic grade attributed to a dismembered metamorphic sole (Pal and Bhattacharya 2010).

Spatial distribution of these mantle rocks with contrasting compositions opens up a debate on whether the distinct geochemical signatures are a reflection of switchover of tectonic setting. Are we looking at two different mantle domains? If yes, does this spatial distribution reflect variations linked to the melting history where the same suboceanic mantle underwent different styles of melting in different sub-arc domain? And were they tectonically juxtaposed, or is one older than, and the protolith of the other?
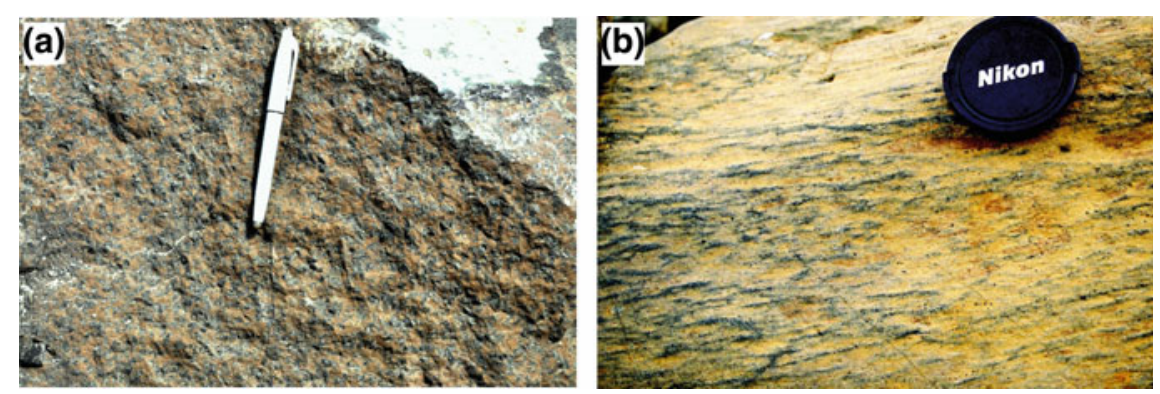

Fig. 3 Collage of field photographs showing variation of mantle peridotites. a Lherzolite from Panchawati, Middle Andaman; b Foliated harzburgite from Rutland Island 


\subsection{Volcanic Rocks}

These are the most extensively studied rock types of the Andaman Ophiolite suite (Ray et al. 1988; Jafri et al. 1990, 2010; Srivastava et al. 2004; Pal 2011; Bhattacharya et al. 2013; Jafri and Sheikh 2013; Ghosh et al. 2014). The volcanic rocks of the Andaman Ophiolite are divided into (a) pillow lava (basaltic) and (b) East Coast volcanics (basalts, basaltic andesites and acid differentiates) (Ray et al. 1988), each having their own field and geochemical characteristics (Fig. 4). The East Coast volcanics are commonly brecciated and accompanied by a pyroclastic (agglomerates) facies (Pal et al. 2003; Sarma et al. 2010). Agglomerates are mostly of andesitic composition, either include abundant fragments of diorite-plagiogranite suite of rocks (at the southeast coast of South Andaman) and or occur in proximity (in Panchawati Coast, Middle Andaman). Vohra et al. (1989) described these two volcanic groups as upper lava and lower lava respectively. The two volcanic rock groups, upper and lower lava found in different thrust slices, often as large blocks along the east coast, overthrust by ophiolitic melange and the ophiolites proper, and are compositionally distinct. The pillow basalts are MORB like (Jafri et al. 2010; Srivastava et al. 2004) while the East Coast volcanics have an island arc affinity (Ray 1985). Further, they have been intruded by plagiogranites which also have an island arc affinity (Jafri et al. 1995). Pal (2011) described the upper lava as island arc tholeiitic (IAT) basalt and the lower lava as low-Ca boninite and correlated them with two distinct types of subduction related magmatism. The author interpreted stratigraphically older boninitic rocks as derived from a source depleted in $\mathrm{Nb}$ and $\mathrm{Y}$ in the first phase, and stratigraphically younger IAT magmas were generated from a less depleted source, contaminated by slab-derived components in a suprasubduction zone setting in the second phase. Jafri and Sheikh (2013) correlated the pillow basalts from Bompoka Island, Nicobar with the pillows of South Andaman and described them as geochemically akin to backarc basin basalts.
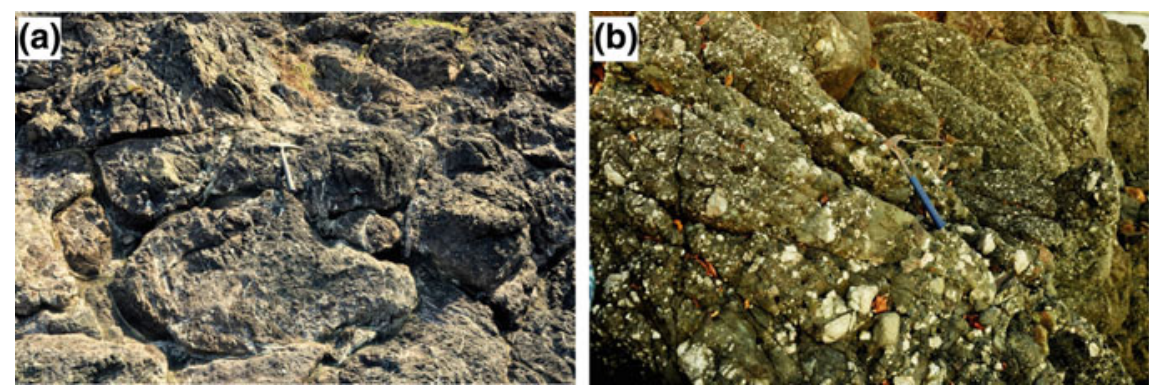

Fig. 4 Collage of field photographs showing variation of volcanic rocks. a Pillow basalts from Corbyn's Cove, South Andaman; b Agglomerate facies of the East Coast volcanics (containing fragments of felsic rock, volcanic rock, embedded in Andesitic matrix) from Chidiyatapu, South Andaman 


\section{Discussion}

Tethyan ophiolites are generally regarded as subduction-related ophiolites (Wakabayashi and Dilek 2003; Dilek and Furnes 2009) and ophiolites of Andaman Islands are no exception (e.g., Ghosh et al. 2009, 2018; Pal 2011). The internal structure and geochemistry of the Phanerozoic ophiolites in the Indonesian orogenic belt show a complex pattern of igneous accretion that involved multiple stages and sources of melt evolution and life cycles in suprasubduction zone environments (Shervais 2001; Dilek and Flower 2003). A stocktaking of the recent researches on Andaman Ophiolite highlights the gap areas where the future research should be directed into.

\subsection{Age of the Ophiolite?}

The diversity of Andaman Ophiolite in terms of petrological and geochemical variability of mantle peridotites and volcanics is quite distinctive. Plagiogranites from two nearby locations on South Andaman, with their island arc geochemical signatures and intimate association with the East Coast volcanics, have been dated at two locations using U/Pb on zircon: A 93.6 $\pm 1.3 \mathrm{Ma}$ age was derived from a plagiogranite dyke intruded the East Coast volcanics (Sarma et al. 2010) and a $95 \pm 2$ Ma age was derived from a plagiogranite sample (Pedersen et al. 2010) which the authors described as 'in situ' whereas at the sampling location, there is only plagiogranite in volcanic agglomerate present, so presumably it was an agglomerate block. These ages were interpreted as the spreading age of Andaman ophiolitic crust (Pedersen et al. 2010), and correlated with other classical Neotethyan ophiolites in Oman (96$95 \mathrm{Ma}$; Rioux et al. 2012, 2013) and the ophiolites of the Eastern Mediterranean region ( 94-90 Ma; Dilek and Furnes 2011; van Hinsbergen et al. 2016, and references therein). The compositional similarity between the plagiogranites and the East Coast volcanics in terms of major, minor, trace elements, $\mathrm{REE}$ and the $\mathrm{Rb} / \mathrm{Sr}$ ratio coupled with their close spatial association, however, establishes their genetic linkage (Jafri et al. 1995). The lithology and geochemistry of the East Coast volcanics with their abundant pyroclastic components and the plagiogranites of Andaman Ophiolite, with their common island arc geochemical affinity may instead represent a matured arc magmatism that intruded and overlies the Andaman Ophiolite. So, what does this $\sim 95 \mathrm{Ma}$ age really indicate? Does it represent the true age of the ophiolite and if it does, then how does it fit to the regional geodynamic setting where the zircons of plagiogranites from Nagaland-Manipur Ophiolite and Kalaymyo Ophiolite (Myanmar), located farther north along the same ophiolite belt gave ages of $116.4 \pm 2.2$ to $118.8 \pm 1.2 \mathrm{Ma}$ (Singh et al. 2017); $117.55 \pm 0.55 \mathrm{Ma}$ and $116.63 \pm 0.30 \mathrm{Ma}$ (Aitchison et al. 2019) and $127 \mathrm{Ma}$ (Liu et al. 2016) respectively?

Alternatively, if the $\sim 95$ Ma event in the evolutionary history of Andaman Ophiolite represents arc maturity, then when did the subduction begin? If we consider Izu-Bonin-Mariana (IBM) as a modern analogue of SSZ ophiolite as pointed out by 
Stern et al. (2012), there is an age gap of nearly 8 Myr between the forearc basalts and contemporary bottom cumulates (gabbros) and normal arc magmatism (Ishizuka et al. 2011). This evolution from subduction initiation to arc normalcy occurred all along the entire length of the IBM subduction system. In Andaman, we have not dated the layered gabbros or any volcanic unit yet other than that they are overlain by upper Cretaceous (Campanian) cherts (Ling et al. 1996). In absence of such age constraints, we do not know the true age of subduction initiation. One way forward is studying the sub-ophiolitic metamorphic rocks identified by Pal and Bhattacharya (2010). Do these have mid-pressure and high-temperature metamorphic paragenesis typical of metamorphic soles (e.g., Agard et al. 2016)? If so, their cooling ages may help identify forearc extension and magmatism-which is typically synchronous and likely caused by suprasubduction zone spreading (van Hinsbergen et al. 2015). If present, garnet-bearing sole rocks may allow dating the inception of metamorphic sole growth that may predate ophiolite spreading and sole exhumation by $>10$ Myr (Guilmette et al. 2018). Zircon from the metamorphic sole of the Kalaymyo Ophiolite, Myanmar yielded a ca. 115 Ma age (Liu et al. 2016) which shows that subduction and upper plate extension were long underway along-strike to the north well before $95 \mathrm{Ma}$. We can also note the existence of the ${ }^{40} \mathrm{Ar} /{ }^{39} \mathrm{Ar}$ plateau age of $106 \pm 3 \mathrm{Ma}$ (Ray et al. 2015) for the plagioclase xenocryst, hosted in Barren lava flow and interpreted as pieces of the Barren island Basement. Does this age reflect the age of the ocean floor below Barren Island? If so, Andaman ophiolite must have been attesting for some ophiolite spreading as early as $106 \mathrm{Ma}$.

\subsection{Emplacement Mechanism?}

Two contrasting models have been proposed for uplift and emergence of the Andaman Ophiolite in absence of obduction onto a major continent. One model suggested that the subduction has been continuing along the western margin of the island arc since the late Cretaceous, and that the ophiolites represent thrust wedges offscraped from a downgoing plate, forming accreted nappes during this prolonged period of subduction (Curray et al. 1979; Mukhopadhyay and Dasgupta 1988; Pal et al. 2003; Curray 2005). By analogy, this model postulates an accretionary prism setting for the uplift and emergence of Andaman Ophiolite. In this context what does the geochemical fingerprinting of the magmatic rocks and presence of metamorphic sole indicate? Do they support the above model? On the contrary, the flat-lying mode of occurrence of the Andaman Ophiolite and their close spatial relationship to a zone of negative gravity anomalies led to an alternative model. This model regarded the Andaman Ophiolite as rootless subhorizontal bodies without much extension at depth. They are interpreted to occur as westward propagated nappes from the eastern ophiolite belt where they were accreted during Middle Eocene to Late Oligocene, much before the currently active subduction (Acharyya et al. 1990; Sengupta et al. 1990; Acharyya 2007). However, field observations certainly challenge the flat-lying mode of occurrence of Andaman Ophiolite in many places, specially in South Andaman. While 
the recent literatures discuss the SSZ origin of the Andaman Ophiolite (Ghosh et al. 2009, 2013; Pal 2011), none of the above models considered them derived from the upper plate.

Emplacement of SSZ ophiolites could be either Cordilleran-type, involving underplating of material in the accretionary prism (accretionary uplift), or Tethyan-type, where the upper plate is thrusted over passive continental margin (Wakabayashi and Dilek 2003; Dilek and Furnes 2009) by obduction (Coleman 1971; Moores 1982; Shervais 2001; Dilek 2003). In the present context the geophysical evidences like a prominent gravity anomaly (Kumar et al. 2013) and a seismic profile (Singh et al. 2013) across the Andaman-Nicobar accretionary ridge suggest the presence of (micro)continental body derived from the Indian plate below the ophiolites, which may have contributed to the uplift, although its underthrusting left no accretionary record (Fig. 5). What is at stake in resolving this emplacement issue?

The heart of the problem lies in how we interpret the ophiolite record, in particular, with regard to plate tectonic reconstructions. Recently, Ghosh et al. (2017) proposed a model where the morphology of the present Andaman-Nicobar outer arc high is explained as the resultant of coalescence of two accretionary prisms, each belonging to a temporally and spatially different subduction system. The initial subduction formed the varieties of petrologically and geochemically distinct oceanic lithosphere in different sub-arc domains (Fig. 5a, b). The emplacement of this oceanic lithosphere was unlike typical Tethyan-type ophiolites because before its uplift due to underthrusting of the geophysically imaged microcontinental block (Fig. 5c) the upper plate was shortened by thrusting and the subduction margin was charged with sediments that accreted at the leading age of the overriding plate, resembling to some extent a cordilleran-type ophiolites. This is also supported by the E-W swath profile across Andaman-Nicobar accretionary ridge (Bandopadhyay and Carter 2017a).

Following this, a second subduction was initiated by induced nucleation to the west of the microcontinent in response to strong compressional force. This mechanism might have emplaced the segment of backarc lithosphere formed by ea0rlier subduction at the top and also produced thrust imbrication within the upper plate (Fig. 5d). This is in accord with the findings of various thrust contacts within the ophiolitic lithounits and other accreted sediment packages (Ray et al. 1988; Pal et al. 2003). The new induced subduction with its gradual maturity started arc volcanism at Barren and Narcondam, and finally resulted in opening of the East Andaman Basin, the backarc basin in early Miocene. Major sediment inputs from the river delta system(s) to the north together with the offscraped sediments of the Indian ocean floor constitutes the younger accretionary prism belonging to the Miocene subduction system. Thus Andaman Ophiolite formed by spreading and subsequent arc magmatism above a subduction zone in the Cretaceous, were overlain by forearc sediments in the Palaeocene-Eocene, and subsequently thrusted in the Eo-Oligocene by upper plate shortening, after which they were underthrusted and uplifted by the Bengal-Nicobar fan that accreted as a lower-plate derived accretionary prism exposed west of the Jarawa thrust.

A little different view may be developed from a recent postulation of Advokaat et al. (2018) who linked the Cretaceous initiation of subduction and the subsequent 


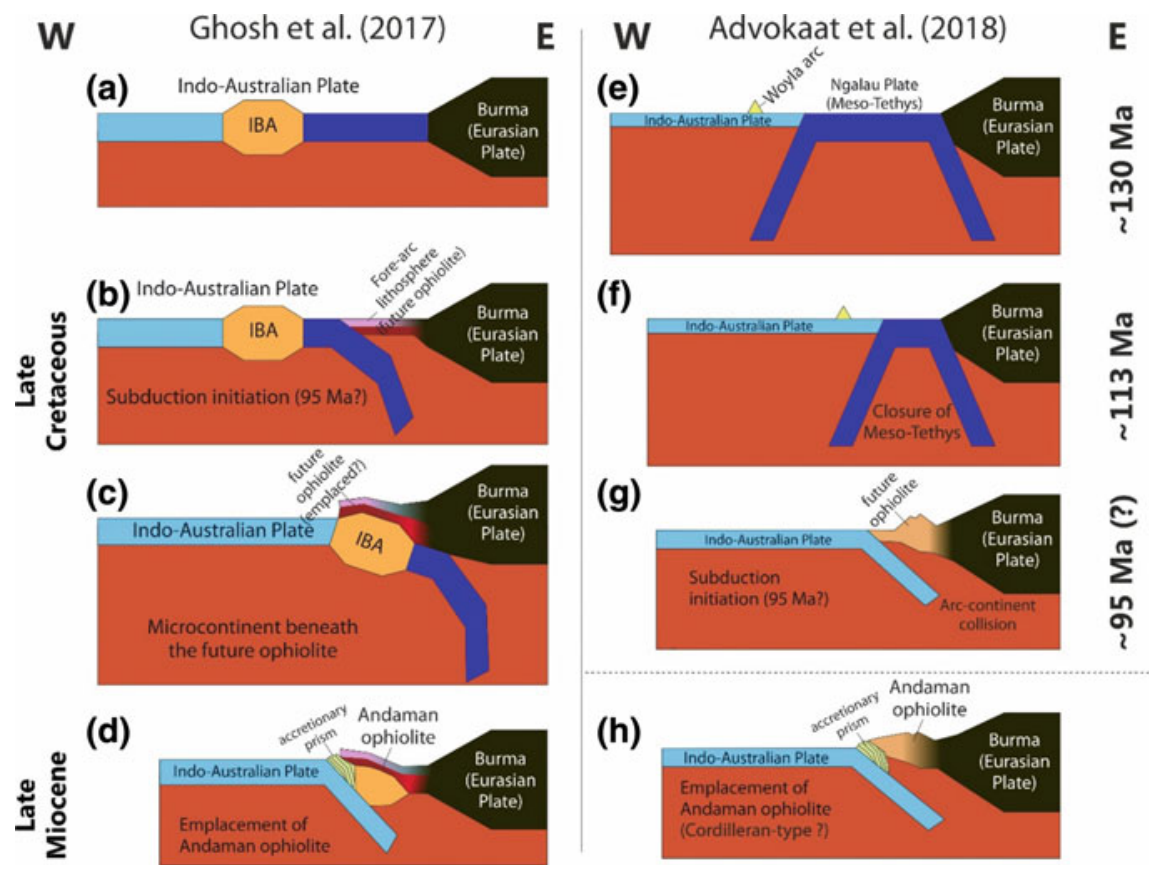

Fig. 5 Schematic diagram illustrating views on possible geodynamic evolution including the origin, evolution and emplacement of Andaman ophiolite at stages. Left panel (a-d) is a simplified version of Fig. 7.7 of Ghosh et al. (2017). The right panel (e-g) is drawn based on reconstruction and kinematic scenario proposed by Advokaat et al. (2018); Fig. 7.C). (a-b) Subduction initiation and formation of forearc lithosphere (future Andaman ophiolite). c Strong slab pull dragged the Indo-Burma-Andaman (IBA) microcontinent beneath the upper plate (future ophiolite), similar to Tethyan-type ophiolite emplacement mechanism. d Final emplacement more akin to Cordillerantype, might be associated with the formation of accretionary prism due to the second phase of subduction beneath the microcontinent. (e-f) Double sided subduction of Ngalau plate leading to closure of Meso-Tethys and formation of Woyla Arc. g Collision of Woyla Arc and Eurasian plate leading to east verging subduction (subduction polarity reversal). (h) Hypothetical Cordillerantype emplacement of Andaman ophiolite. Please note, Ghosh et al. (2017) did not consider the Woyla history in their model. Similarly, geophysically imaged Indo-Burma-Andaman (IBA) microcontinent was not addressed by Advokaat et al. (2018) and does not exclude the microcontinent being later subducted. So, in our point of view, these two models are not mutually exclusive and hence should not be considered as alternatives

formation of the Andaman ophiolitic crust to a subduction polarity reversal following collision of the Woyla arc of west Sumatra with Sundaland (Eurasia) (Fig. 5e-g). This would place the Andaman lithosphere in an original backarc position prior to inception of subduction at the western edge of the Woyla arc, opening opportunities to explain the contrasting geochemical signatures. Uplift and subsidence of the ophiolites recorded in shallow marine Palaeogene and deep-marine Oligo-Miocene sediments (Bandopadhyay and Carter 2017b, c) and alluded to above may result from 
the interplay of sediment or microcontinental crustal accretion, and subduction erosion and upper plate shortening. The detailed analysis of deformation, magmatism, metamorphism, and sedimentation of the Andaman Ophiolite in context of Myanmar and Sumatra geology and India-Australia-Asia plate motion will allow the further unlocking of the forearc archive of subduction in the Andaman-Nicobar archipelago.

\section{Conclusion}

Studies reveal that Andaman Ophiolite plays a crucial role in unravelling the IndiaEurasia collisional history and global geodynamics as well. Petrochemical studies on the various litho-member confirm its suprasubduction zone origin (Ghosh et al. 2013; Pal 2011), however, some key questions have not yet been critically addressed. This contribution summarizes the major findings and highlights the gap areas.

(1) Volcanic rocks of Andaman Ophiolite are geochemically the most diverse rock types and they have been divided into-(i) Pillow basalts, akin to MORB characters and (ii) East coast volcanics with island arc affinity. The origin of these two volcanic groups of rocks has been interpreted variously by earlier workers who attempted to fit them in various tectonic settings. However, a comprehensive geochemical study of the volcanic rocks with reference to their field dispositions are still lacking.

(2) The mantle sections of the Andaman Ophiolite also demonstrate their variation over the islands. This has been explained in terms of variation in degree of melting and mode of melting specific to tectonic settings. Mantle peridotites of Rutland Island dominantly represent arc peridotites (Ghosh et al. 2009, 2013) whereas that in Middle and North Andaman are akin to backarc basin peridotites (Ghosh et al. 2018). Spatial distribution of these two contrasting mantle rocks and their association with other rock types point towards a complex evolution of the Andaman Ophiolite.

(3) U-Pb zircon ages from plagiogranites of Andaman Ophiolite yielded 93-95 Ma age (Pedersen et al. 2010; Sarma et al. 2010) which has been correlated with global Neotethyan subduction initiation (ca. $95 \mathrm{Ma}$ ). In case this age is assigned to the age of Andaman Ophiolite it is difficult to fit in the regional geodynamic setting of this region because two neighbouring ophiolites from NagalandManipur and Myanmar, both lying farther north along the same ophiolite belt date $117 \mathrm{Ma}$ (Singh et al. 2017, Aitchison et al. 2019) and $127 \mathrm{Ma}$ (Liu et al. 2016) respectively. Field and geochemical studies of Andaman plagiogranites indicate that the $\sim 95 \mathrm{Ma}$ age should be assigned to arc maturity. If so, this age may not approximate the age of subduction initiation, because in Oman subduction initiation dated from prograde garnet of metamorphic sole predate the forearc spreading by at least $8 \mathrm{Ma}$ (Guilmette et al. 2018). Sub-ophiolitic metamorphic sole from Andaman Ophiolite is reported, but not dated yet. Detailed thermobarometric, geochemical, and geochronological studies in particular of the 
sole rocks and gabbroic cumulates might unravel the real story of the evolution of Andaman Ophiolite.

Acknowledgements This work is part of the doctoral research $(\mathrm{PhD})$ program of the first author, supported with DST INSPIRE Fellowship (IF 130148). BG acknowledges financial support received from Science and Engineering Research Board, DST, India (EMR/2017/000929). DJJvH acknowledges a Netherlands Organization for Scientific Research (NWO) VICI grant 865.17.001. Authors acknowledge the help received from Debojit Talukdar and Ashish Raul in preparing the DEM map. J.S. Ray and M. Radhakrishna, Editors of this monograph are thankfully acknowledged for their invitation to submit this article. Hetu Sheth and one anonymous reviewer are thanked for their insightful comments and suggestions that significantly improved the quality of the manuscript.

\section{References}

Acharyya SK (2007) Collisional emplacement history of the Naga-Andaman Ophiolite and the position of the eastern Indian suture. J Asian Earth Sci 29(2):229-242

Acharyya S, Ray K, Sengupta S (1990) Tectonics of the ophiolite belt from Naga Hills and Andaman Islands, India. Proc Indian Acad Sci-Earth Planet Sci 99(2):99-187

Advokaat EL, Bongers MLM, Rudyawan A, BouDagher-Fadel MK, Langereis CG, van Hinsbergen DJJ (2018) Early Cretaceous origin of the Woyla Arc (Sumatra, Indonesia) on the Australian plate. Earth Planet Sci Lett 498:348-361

Agard P, Yamato P, Soret M, Prigent C, Guillot S, Plunder A, Dubacq B, Chauvet A, Monié P (2016) Plate interface rheological switches during subduction infancy: control on slab penetration and metamorphic sole formation. Earth Planet Sci Lett 451:208-220. https://doi.org/10.1016/j.epsl. 2016.06.054

Aitchison JC, Ao A, Bhowmik S, Clarke GL, Ireland TR, Kachovich S, Lokho K, Stojanovic D, Roeder T, Truscott N, Zhen Y, Zhou R (2019) Tectonic evolution of the Western Margin of the Burma microplate based on new fossil and radiometric age constraints. Tectonics 38(5):17181741. https://doi.org/10.1029/2018tc005049

Anonymous (1972) Penrose field conference on ophiolites. Geotimes 17:24-25

Awasthi N (2017) Provenance and paleo-weathering of Tertiary accretionary prism-forearc sedimentary deposits of the Andaman Archipelago, India. J Asian Earth Sci 150:45-62

Bandopadhyay PC, Carter A (2017a) Chapter 2 Introduction to the geography and geomorphology of the Andaman-Nicobar Islands. In: Bandopadhyay PC, Carter A (eds) The Andaman-Nicobar accretionary ridge: geology, tectonics and hazards, vol 47. Geological Society, London, Memoirs, pp 9-18

Bandopadhyay PC, Carter A (2017b) Chapter 8 Mithakhari deposits. In: Bandopadhyay PC, Carter A (eds) The Andaman-Nicobar accretionary ridge: geology, tectonics and hazards, vol 47. Geological Society, London, Memoirs, pp 111-132

Bandopadhyay PC, Carter A (2017c) Chapter 9 Submarine fan deposits: petrography and geochemistry of the Andaman Flysch. In: Bandopadhyay PC, Carter A (eds) The Andaman-Nicobar accretionary ridge: geology, tectonics and hazards, vol 47. Geological Society, London, Memoirs, pp 133-140

Beccaluva L, Coltorti M, Galassi B, Macciotta G, Siena F (1994) The Cainozoic calcalkaline magmatism of the western Mediterranean and its geodynamic significance. Bollettino di Geofisica Teorica ed Applicata 36:293-308

Bédard JH, Lauzière K, Tremblay A, Sangster A (1998) Evidence for forearc seafloor-spreading from the Betts Cove ophiolite, Newfoundland: oceanic crust of boninitic affinity. Tectonophysics 284(3):233-245 
Bhattacharya A, Pal T, Ghosh B (2013) Characterization of the accreted ophiolite slices of Rutland Island, Andaman Sea: evolution in a suprasubduction zone setting. Ofioliti 38(2):121-142

Coleman RG (1971) Plate tectonic emplacement of upper mantle peridotites along continental edges. J Geophys Res 76(5):1212-1222

Curray JR (2005) Tectonics and history of the Andaman Sea region. J Asian Earth Sci 25(1):187-232

Curray JR, Moore DG, Lawver LA, Emmel FJ, Raitt RW, Henry M, Kieckhefer R (1979) Tectonics of the Andaman Sea and Burma. In: Watkins JS, Montadert L, Dickerson PW (eds) Geological and geophysical investigations of continental margins, AAPG Memoir, vol 29. American Association of Petroleum Geologists, pp 189-198

Dewey JF (1976) Ophiolite obduction. Tectonophysics 31(1):93-120

Dilek Y (2003) Ophiolite concept and its evolution. In: Dilek Y, Newcomb S (eds) Ophiolite concept and the evolution of geological thought, GSA Special Papers, vol 373. Geological Society of America, pp 1-16

Dilek Y, Flower MFJ (2003) Arc-trench rollback and forearc accretion: 2. A model template for ophiolites in Albania, Cyprus, and Oman. In: Dilek Y, Robinson PT (eds) Ophiolites in earth history, vol 218. Geological Society, London, Special Publications, pp 43-68

Dilek Y, Furnes H (2009) Structure and geochemistry of Tethyan ophiolites and their petrogenesis in subduction rollback systems. Lithos 113(1):1-20

Dilek Y, Furnes H (2011) Ophiolite genesis and global tectonics: geochemical and tectonic fingerprinting of ancient oceanic lithosphere. GSA Bull 123(3-4):387-411

Dilek Y, Furnes H (2014) Ophiolites and their origins. Elements 10(2):93-100

Dilek Y, Moores E (1990) Regional tectonics of the eastern Mediterranean ophiolites. In: Malpas J, Moores E, Panayiotou A, Xenophontos C (eds) Ophiolites, oceanic crustal analogues, proceedings of the symposium "Troodos 1987", pp 295-309

Dilek Y, Thy P, Hacker B, Grundvig S (1999) Structure and petrology of Tauride ophiolites and mafic dike intrusions (Turkey): implications for the Neotethyan ocean. GSA Bull 111(8):1192-1216

Furnes H, de Wit M, Dilek Y (2014) Precambrian greenstone belts host different ophiolite types. In: Dilek Y, Furnes H (eds) Evolution of Archean crust and early life. Springer Netherlands, Dordrecht, pp 1-22

Ghosh B, Bandyopadhyay D, Morishita T (2017) Andaman-Nicobar ophiolites, India: origin, evolution and emplacement. In: Bandopadhyay PC, Carter A (eds) The Andaman-Nicobar accretionary ridge: geology, tectonics and hazards, vol 47. Geological Society, London, Memoirs, pp 95-110

Ghosh B, Morishita T, Bhatta K (2013) Significance of chromian spinels from the mantle sequence of the Andaman ophiolite, India: paleogeodynamic implications. Lithos 164-167:86-96

Ghosh B, Morishita T, Gupta BS, Tamura A, Arai S, Bandyopadhyay D (2014) Moho transition zone in the Cretaceous Andaman ophiolite, India: a passage from the mantle to the crust. Lithos 198-199:117-128

Ghosh B, Mukhopadhyay S, Morishita T, Tamura A, Arai S, Bandyopadhyay D, Chattopadhaya S, Ovung TN (2018) Diversity and evolution of suboceanic mantle: constraints from Neotethyan ophiolites at the eastern margin of the Indian plate. J Asian Earth Sci 160:67-77

Ghosh B, Pal T, Bhattacharya A, Das D (2009) Petrogenetic implications of ophiolitic chromite from Rutland Island, Andaman - a boninitic parentage in supra-subduction setting. Mineral Petrol 96(1):59

Guilmette C, Smit MA, van Hinsbergen DJJ, Gürer D, Corfu F, Charette B, Maffione M, Rabeau O, Savard D (2018) Forced subduction initiation recorded in the sole and crust of the Semail ophiolite of Oman. Nat Geosci 11(9):688-695

Hall R (2002) Cenozoic geological and plate tectonic evolution of SE Asia and the SW Pacific: computer-based reconstructions, model and animations. J Asian Earth Sci 20(4):353-431

Hutchison CS (1975) Ophiolite in Southeast Asia. GSA Bull 86(6):797-806

Imsong W, Choudhury S, Phukan S (2016) Ascertaining neotectonic activities in the southern part of Shillong plateau through geomorphic parameters and remote sensing data. Curr Sci 110(1):91-98 
Ishizuka O, Tani K, Reagan MK, Kanayama K, Umino S, Harigane Y, Sakamoto I, Miyajima Y, Yuasa M, Dunkley DJ (2011) The timescales of subduction initiation and subsequent evolution of an Oceanic Island arc. Earth Planet Sci Lett 306(3):229-240

Jafri SH, Balaram V, Ramesh SL (1990) Geochemistry of Andaman-Nicobar Island basalts: a case for a possible plume origin. J Volcanol Geoth Res 44(3):339-347

Jafri SH, Charan SN, Govil PK (1995) Plagiogranite from the Andaman ophiolite belt, Bay of Bengal, India. J Geol Soc 152(4):681-687

Jafri SH, Sarma DS, Sheikh JM (2010) Hyaloclastites in pillow basalts, South Andaman Island, Bay of Bengal, India. Curr Sci 99(12):1825-1829

Jafri SH, Sheikh JM (2013) Geochemistry of pillow basalts from Bompoka, Andaman-Nicobar Islands, Bay of Bengal, India. J Asian Earth Sci 64:27-37

Karunakaran C, Pawde MB, Raina VK, Ray KK, Saha SS (1964) Geology of South Andaman Island, India. Reports of 22nd international geological congress, New Delhi, vol 11, pp 79-100

Karunakaran C, Ray KK, Saha SS (1967) A revision of the stratigraphy of Andaman and Nicobar Islands, India. Bull Natl Inst Sci India 38:436-441

Ling HY, Chandra R, Karkare SG (1996) Tectonic significance of Eocene and Cretaceous radiolaria from South Andaman Island, northeast Indian Ocean. Island Arc 5(2):166-179

Liu C-Z, Chung S-L, Wu F-Y, Zhang C, Xu Y, Wang J-G, Chen Y, Guo S (2016) Tethyan suturing in Southeast Asia: Zircon U-Pb and Hf-O isotopic constraints from Myanmar ophiolites. Geology 44(4):311-314

Maffione M, Thieulot C, van Hinsbergen DJJ, Morris A, Plümper O, Spakman W (2015) Dynamics of intraoceanic subduction initiation: 1. Oceanic detachment fault inversion and the formation of supra-subduction zone ophiolites. Geochem Geophys Geosyst 16:1753-1770

Moores EM (1982) Origin and emplacement of ophiolites. Rev Geophys 20(4):735-760

Moores EM, Kellogg LH, Dilek Y (2000) Tethyan ophiolites, mantle convection, and tectonic "historical contingency": A resolution of the "ophiolite conundrum". In: Dilek Y, Moores EM, Elthon D, Nicolas A (eds) Ophiolites and oceanic crust: new insights from field studies and the Ocean Drilling Program, GSA Special Papers, vol 349. Geological Society of America, pp 3-12

Morishita T, Yoshikawa M, Tamura A, Guotana JM, Ghosh B (2018) Petrology of peridotites and $\mathrm{Nd}-\mathrm{Sr}$ isotopic composition of their clinopyroxenes from the middle Andaman ophiolite, India. Minerals 8(9):410. https://doi.org/10.3390/min8090410

Mukhopadhyay M, Dasgupta S (1988) Deep structure and tectonics of the Burmese arc: constraints from earthquake and gravity data. Tectonophysics 149(3):299-322

Pal T (2011) Petrology and geochemistry of the Andaman ophiolite: melt-rock interaction in a suprasubduction-zone setting. J Geol Soc 168(4):1031-1045

Pal T, Bhattacharya A (2010) Greenschist-facies sub-ophiolitic metamorphic rocks of Andaman Islands, Burma-Java subduction complex. J Asian Earth Sci 39(6):804-814

Pal T, Bhattacharya A (2011) Block-and-ash flow deposit of the Narcondam Volcano: product of dacite-andesite dome collapse in the Burma-Java subduction complex. Island Arc 20(4):520-534. https://doi.org/10.1111/j.1440-1738.2011.00782.x

Pal T, Chakraborty PP, Gupta TD, Singh CD (2003) Geodynamic evolution of the outer-arc-forearc belt in the Andaman Islands, the central part of the Burma-Java subduction complex. Geol Mag 140(3):289-307

Pedersen RB, Searle MP, Carter A, Bandopadhyay PC (2010) U-Pb zircon age of the Andaman ophiolite: implications for the beginning of subduction beneath the Andaman-Sumatra arc. J Geol Soc 167(6):1105-1112

Ratheesh Kumar RT, Windley BF, Rajesh VJ, Santosh M (2013) Elastic thickness structure of the Andaman subduction zone: implications for convergence of the Ninetyeast Ridge. J Asian Earth Sci 78:291-300

Ray JS, Pande K, Bhutani R (2015) ${ }^{40} \mathrm{Ar} /{ }^{39} \mathrm{Ar}$ geochronology of subaerial lava flows of Barren Island volcano and the deep crust beneath the Andaman Island Arc, Burma Microplate. Bull Volcanol 77:57. https://doi.org/10.1007/s00445-015-0944-9 
Ray KK (1985) East Coast Volcanics: a new suite in the ophiolite of Andaman Islands. Rec Geol Surv India 116(2):83-87

Ray KK, Sengupta S, van Den Hul HJ (1988) Chemical characters of volcanic rocks from Andaman ophiolite, India. J Geol Soc 145(3):393-400

Rioux M, Bowring S, Kelemen P, Gordon S, Dudás F, Miller R (2012) Rapid crustal accretion and magma assimilation in the Oman-U.A.E. ophiolite: high precision U-Pb zircon geochronology of the gabbroic crust. J Geophys Res Solid Earth 117(B7):B07201. https://doi.org/10.1029/ 2012jb009273

Rioux M, Bowring S, Kelemen P, Gordon S, Miller R, Dudás F (2013) Tectonic development of the Samail ophiolite: high-precision U-Pb zircon geochronology and Sm-Nd isotopic constraints on crustal growth and emplacement. J Geophys Res Solid Earth 118(5):2085-2101

Sarma DS, Jafri SH, Fletcher IR, McNaughton NJ (2010) Constraints on the tectonic setting of the Andaman ophiolite, Bay of Bengal, India, from SHRIMP U-Pb Zircon geochronology of plagiogranite. J Geol 118(6):691-697

Sengupta S, Ray KK, Acharyya SK, de Smeth JB (1990) Nature of ophiolite occurrences along the eastern margin of the Indian plate and their tectonic significance. Geology 18(5):439-442

Shervais JW (2001) Birth, death, and resurrection: the life cycle of suprasubduction zone ophiolites. Geochem Geophys Geosyst 2(1):2000GC000080. https://doi.org/10.1029/2000gc000080

Sheth H (2014) What drives centuries-long polygenetic scoria cone activity at Barren Island volcano? J Volcanol Geoth Res 289:64-80. https://doi.org/10.1016/j.jvolgeores.2014.10.019

Sheth HC, Ray JS, Bhutani R, Kumar A, Smitha RS (2009) Volcanology and eruptive styles of Barren Island: an active mafic stratovolcano in the Andaman Sea, NE Indian Ocean. Bull Volcanol 71(9):1021. https://doi.org/10.1007/s00445-009-0280-z

Singh AK, Chung S-L, Bikramaditya RK, Lee HY (2017) New U-Pb zircon ages of plagiogranites from the Nagaland-Manipur Ophiolites, Indo-Myanmar Orogenic Belt, NE India. J Geol Soc 174(1):170-179

Singh SC, Moeremans R, McArdle J, Johansen K (2013) Seismic images of the sliver strike-slip fault and back thrust in the Andaman-Nicobar region. J Geophys Res Solid Earth 118(10):5208-5224

Srivastava RK, Chandra R, Shastry A (2004) High-Ti type N-MORB parentage of basalts from the south Andaman ophiolite suite, India. Proc Indian Acad Sci-Earth Planet Sci 113(4):605-618

Stern RJ, Reagan M, Ishizuka O, Ohara Y, Whattam S (2012) To understand subduction initiation, study forearc crust: to understand forearc crust, study ophiolites. Lithosphere 4(6):469-483. https://doi.org/10.1130/L183.1

van Hinsbergen DJJ, Maffione M, Plunder A, Kaymakcı N, Ganerød M, Hendriks BWH, Corfu F, Gürer D, de Gelder GINO, Peters K, McPhee PJ, Brouwer FM, Advokaat EL, Vissers RLM (2016) Tectonic evolution and paleogeography of the Kırşehir Block and the Central Anatolian Ophiolites, Turkey. Tectonics 35(4):983-1014

van Hinsbergen DJJ, Peters K, Maffione M, Spakman W, Guilmette C, Thieulot C, Plümper O, Gürer D, Brouwer FM, Aldanmaz E, Kaymakc1 N (2015) Dynamics of intraoceanic subduction initiation: 2. Suprasubduction zone ophiolite formation and metamorphic sole exhumation in context of absolute plate motions. Geochem Geophys Geosyst 16(6):1771-1785. https://doi.org/ $10.1002 / 2015 \mathrm{gc} 005745$

Vohra CP, Haldar D, Roy AKG (1989) The Andaman-Nicobar ophiolite complex and associated mineral resources - current appraisal. In: Ghose NC (ed) Phanerozoic ophiolites of India. Sumna Publishers and Distributers, India, pp 281-315

Wakabayashi J, Dilek Y (2003) What constitutes 'emplacement' of an ophiolite?: Mechanisms and relationship to subduction initiation and formation of metamorphic soles. In: Dilek Y, Robinson PT (eds) Ophiolites in Earth History, vol 218. Geological Society, London, Special Publications, pp 427-447

Workman RK, Hart SR (2005) Major and trace element composition of the depleted MORB mantle (DMM). Earth Planet Sci Lett 231(1-2):53-72. https://doi.org/10.1016/j.epsl.2004.12.005 